International Journal of Engineering \& Technology, 7 (2.7) (2018) 1066-1071
International Journal of Engineering \& Technology
SPC
Website: www.sciencepubco.com/index.php/IJET
Research paper

\title{
Stress at work place and its impact on employee performance
}

\author{
Ch Lakshmi Narahari ${ }^{1} *$, Kalpana Koneru ${ }^{1}$ \\ ${ }^{1}$ Department of Management Studies, VFSTR, Vadlamudi, Guntur (Dt.), AP \\ *Corresponding author E-mail: kalpanarao.koneru@gmail.com
}

\begin{abstract}
The emphasis on management of Stress at work place (WS) in the corporate world assumes that the ability to manage Stress at work place is associated with enhanced employee performance which suggests that WS is a vital tool having sturdy and significant impact on both em-ployee's employee performance and overall employee performance. Performance is important as it determines the survival of the organiza-tion and it also reflects how the organization can cope in today's challenging business environment. The current paper is an attempt to brief the work done in the field of WS and employee performance by discussing various studies conducted around the world. The current paper has compiled the works done on the connection between Stress at work place and workplace performance and based on synthesis of the past studies has created a model that depicts the relationship between the various variables that contribute to Stress at work place and its impact on employee performance.
\end{abstract}

Keywords: Stress at Work Place; Organizational Performance; Employees; Employee Performance.

\section{Introduction}

Stress at work place has always been a matter of discomfort to employees and other in any organization. It not only affects the employee's performance but also the overall performance of the group or project or the organization as a whole. Behavioral theorists, Human Resource Managers, Researcher's agree that stress at work place is a hazardous issue in many organizations. The effects of Stress at work place are very high in many organizations in recent years. For instance, the International Labor Organization (ILO) reports that "the inefficiencies arising from work may cost up to 10 percent of a country's GNP (Christo and Piernaar, 2006)." Literature indicates that "Work Stress is a predominant factor that influences different factors like job satisfaction, leadership, Organizational Performance, conflict management, stress management, work life balance, and also academic performance" (Backs, 2001; Christo and Piernaar, 2006; Schaubroeck et al, 2010). The main objective of this research is to accumulate the work done on the bonding between 'Stresses at work place' \& 'Organizational Performance' thereby toting up to the literature on the same.

\section{Literature review}

\subsection{Stress at work place}

Work stress is known as "the understanding of a disagreement between ecological wants (stressors) and businesses capacity to achieve these wants." (Delve,Skagert\&Vilhelmsson, 2007; Hetland, Sandal \&Johnsen, 2007; Wager, Fieldman\& Hussey 2003). Friese (2015). For example, feeling of loss of occupation, and safety, long working hours, lack of security, and lack of independence in the occupation can cause work stress. Stress at work place is known as "the understanding of a disagreement between ecological wants (stressors) and businesses capacity to achieve these wants.” (Delve,Skagert\&Vilhelmsson, 2007; Hetland, Sandal \&Johnsen, 2007; Wager, Fieldman\& Hussey 2003). Friese (2015) for example, sensitivity or emotion towards of loss of occupation and safety, long working hours, lack of safety and security, and lack of freedom in the organization can cause Stress at work place. Stress in an organization can be caused due to declination of revenue, loss of assets, long working hours, working beyond the specified time, failure towards targets, in ability to meet deadlines, peer pressure and working environment are considered as prime contributors to personnel stress. Stress at work place habitually exhibits extreme displeasure, dissatisfaction, disapproval, discontent and in many cases resulting to frustration among employees. In some cases,transfers, relocation of project, inconsistent Performance affects the interpersonal relationship at work place which may result in unsociable or isolated life style. The diagnosis of stress at work place is always challenging for both the job seeker and job provider as the symptoms of stress at work place were always unexposed or pretended to be normal or ignored. In many cases the job seeker or the job provider doesn't take this as an issue or neither takes any serious action in reducing the stress and its related issues.

Therefore, this research is aimed to find out feasible solutions for stress at work place on individual performance with the organizational performance and interventions that can be implemented by the organization and employees to cope with stress in an effective, systematic and scientific manner. In order to obtain an in depth understanding of these variables; stress at work place, we will initially focus on conceptual understanding of Stress at work place and measure the variable with means of available statistical tools in order to evaluate the performance of the employee and employer from base value to an extreme value.

\subsection{Organizational performance}

Organizational performance has usually been defined as "gathering of profits, manufacturing, service, and stable goals (Friese, 2015)". Employer's concern on the subject of work-related stress 
has normally focused on the how this type of stress effects the production and profits negatively. This conventional definition of employee performance, although, focuses only on part of the equation. Choosing an alternative but more wide-ranging definition of employee performance, Schaubroeck et al (2010) wrote about an advanced opinion of organizational health performance to fight the existing risks and prevent them from occurring again in the work place. Topper (2007) suggested that the heads of the organization shall focus on employee's health in spite of just focusing the profits and manufacturing which he considered as narrow goals.

Researchers have gained a lot of curiosity in discovering the personality and significance of Organizational Performance in the field of industrial psyche. This is interest if because of the significance of organizations. One of the main definitions of Organizational Performance was given by Backs (2001) and according to him employee performances were the steps taken by the organization to analyze the standards set and the actual performance of the company. Ornelas and Kleiner (2003) defined Organizational Performance as the level of achievement after putting in efforts. Performance is a group phenomenon with ecological factors which effect the Performance of an association through their ability and motivational level (Erkutlu\&Chafra, 2006).

Researchers have accumulated a lot of interest on evaluating the personality and its importance on Organizational Performance. This interest is because of the significance of organizations. One of the main definitions of Organizational Performance was given by Backs (2001) and according to him employee performance was the steps taken by the organization to analyze the standards set and the actual performance of the company. Ornelas and Kleiner (2003) defined Organizational Performance as the level of achievement after putting in efforts. Performance is a group phenomenon with ecological factors which effect the Performance of an association through their ability and motivational level (Erkutlu\&Chafra, 2006).

Organizational Performance is the level of effort and organization will put in to achieve its goals (Christo and Piernaar, 2006). Caldwell (2007) defined Organizational Performance as the strategy and plan of an association to perform and complete a work in a particular time period. Kleiner (2003) defined Organizational Performance as the quality and quantity of work one by the group or individual workers. Rayner\&Mclvor (2006) suggested that the feel of Organizational Performance relies on the job requirement, goals, beliefs and objectives of the organization.

\subsection{Relationship between stress at work place and or- ganizational performance}

With the intention to better understand the harmful effects that work-related stress can have on both workers and corporation a research on work-related stress has recommended an association between unmitigated stress and burnout, defining burnout as the primary manifestation of the mental, objective, and behavioral aspects of stress (Friese, 2015), effects on employee performance (Ornelas and Kleiner, 2003). Burnout as a mental circumstance happening in response to chronic stressors has been characterized through the signs of emotional exhaustion, depersonalization, and decreased personal accomplishment (Christo and Piernaar, 2006). further to burnout, work strain can purpose absenteeism, high group of workers turnover, and reduced efficiency and overall performance (Erkutlu\&Chafra, 2006). Researchers have noted that the long-time period effects of non-stop work strain could have poor outcomes for each worker and the corporations wherein they work (Ornelas and Kleiner, 2003). As a end result, work pressure is a developing subject for management due to its dysfunctional outcomes on employee performance.

\section{Research methodology}

The present research employs secondary research method to attain the objectives. the research has analyzed past literature and studies on connection between Stress at work place and employee performance to create a model that explains the factors of employee performance that are impacted due to Stress at work place. This model can be used by practitioners, businesses as well as academicians.

\subsection{Methodology}

The study is systematic, critical and analytical. It gives a detailed description about the stress at work force, problems faced by the employees, methods and tools used to evaluate the performance, and the standards practices implemented to cope with stress. It is a dual practice which focuses both on employee and employer side to deal with the problem or a situation. The data is collected based on the two attributes; the 'Micro Data' and the 'Macro Data.' The Micro data is the data accumulated from the standard sources like libraries, journals, books and web portals where as Macro Date is collected from the employees working in the IT sector where there is a possibility of high stressful environment. A sample of 100 employees is selected to gather the data and well structured questionnaires were designed to gather the data. Utmost care was taken to keep the questionnaires away from errors or mistakes. There questionnaires were tested among these 100 employees keeping the standards of standardized testing and keeping it away from various biases and inclanations.

\subsection{Sampling design}

The Proportionate Stratified Sampling Method was used to select the respondents in IT and IT oriented and BPO sectors in Hyderabad city. This sample consists of employees from Cognizant, Verizon, Valuelabs, Infosys BPO, Tata Consultancy Servises BPO, and HP Technologies Ltd. Professional employees were selected to study the sample. The sample size constitutes of 1 per cent of the universe i.e., 970 employees where as the universe constitutes 97000 employees. The sample space was classified on the basis of their nature of service.

\subsection{Area of the study}

The study was conducted in Hyderabad, India. The IT, IT oriented and BPO Industry in Hyderabad has registered an extensive growth in since a few decades. In the present Scenario, Hyderabad is the second largest producer of IT, IT oriented and BPO employees in India. In this regard, Hyderabad is the most suitable place to conduct this research in India. For this study, Cognizant, Verizon, Valuelabs, Infosys BPO, Tata Consultancy Services BPO, and HP Technologies Ltd. were chosen, as they are the top five IT, IT oriented and BPO companies in the Hyderabad. Therefore, Hyderabad is selected for the study.

\section{Discussion of findings}

The synthesis of past literature has shown that the relationship between work, the work environment, work schedules, and resources and equipment and Stress at work place. This implies that organizational stress is a function of the work environment in any organization. Furthermore, the results also indicate that decrease in productivity, higher attrition rates, debilitated leaves, mishaps, low employment fulfillment, low quality products and services, poor internal communication and clashes inside the corporation are the key consequences of Stress at work place. The results also point out that that stress management has high noteworthy association with worker motivation and profitability. Based on the research findings the following model is constructed: 
(Source: Self Constructed)In order to examine the significant differentiation between demographic profiles of the employees with respect to the stress factors, a t-test is applied. The respondents responses are recorded with respect to the stress factors like, Stress at work place, Peer pressure, time of work, flexibility in working hours, deadline stress, project stress, personal stress, Psychological stress, physical stress, environmental stress, climatic stress, emotional stress, self-respect stress, family stress, social stress, individual, Change stress, Aging stress etc. Such variables are observed and its impact or influence on several factors is recorded. For example impact of stress on work, family, job; organi- zation, individual etc are recorded. The steps taken by the organization in order to cope with the stress like implementing fair working hours, implementing flexible working hours, organizing picnics and team meets, appointing psychological counselors and conducting counseling sessions to its employees is recorded.

H01: There is no significant differentiation between demographic profiles of the employees with respect to the stress factors.

Source: Computed from Primary data * Significant at 5 per cent level

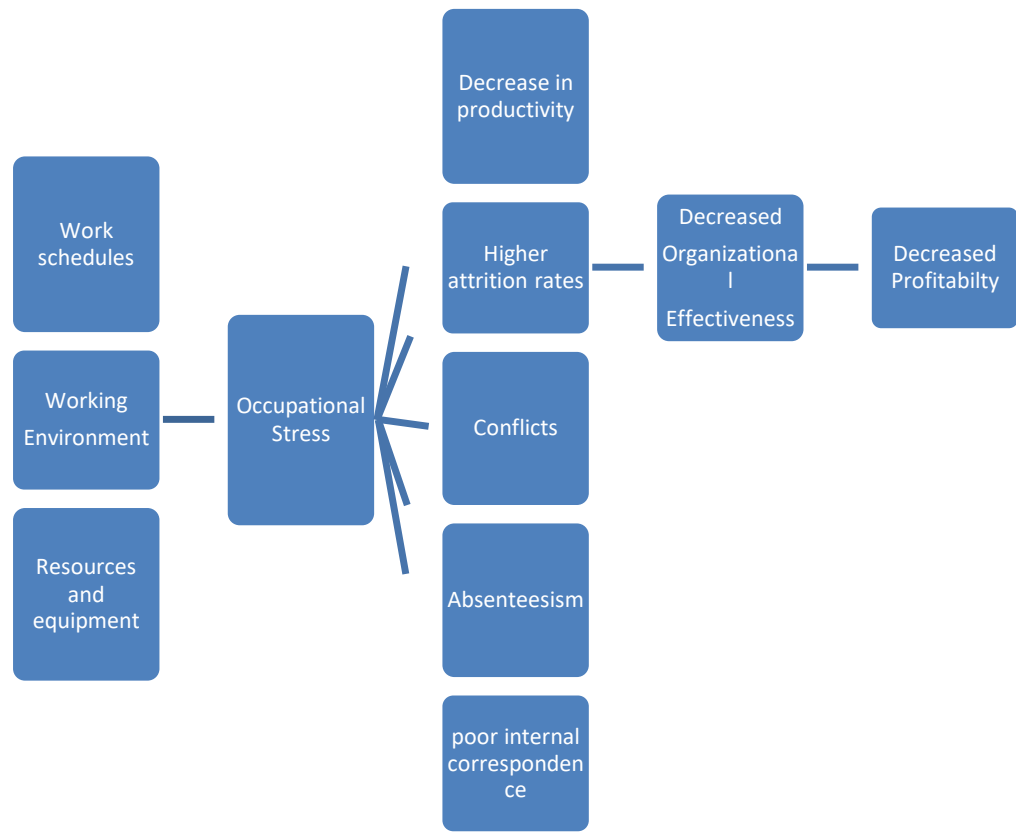

Fig. 1: Model of Relationship between the Various Variables That Contribute To Stress at Work Place and Its Impact on Employee Performance.

Table 1: $T$ Test for Several Stress Factors on the Source of Gender

\begin{tabular}{|c|c|c|c|c|c|c|c|}
\hline Variables & Gender & $\mathrm{N}$ & Mean & SD & SEm & T-Value & Sig. (2-tailed) \\
\hline \multirow{4}{*}{ Nonflexible working hours } & Male & 585 & 48.023 & 4.871 & 0.201 & \multirow{4}{*}{.638} & \multirow{4}{*}{.432} \\
\hline & Female & 385 & 47.824 & 4.342 & 0.222 & & \\
\hline & Total & 973 & 49.848 & 4.566 & 0.181 & & \\
\hline & Male & 583 & 59.608 & 5.067 & 0.210 & & \\
\hline \multirow[t]{3}{*}{ Working Hours Stress } & Female & 387 & 58.585 & 5.748 & 0.292 & \multirow[t]{3}{*}{2.721} & \multirow[t]{3}{*}{$.008^{*}$} \\
\hline & Total & 960 & 58.873 & 5.367 & 0.174 & & \\
\hline & Male & 583 & 62.363 & 6.341 & 0.277 & & \\
\hline \multirow[t]{3}{*}{ Project Stress } & Female & 377 & 61.594 & 6.093 & 0.307 & \multirow[t]{3}{*}{.422} & \multirow[t]{3}{*}{.675} \\
\hline & Total & 960 & 61.679 & 6.229 & 0.207 & & \\
\hline & Male & 573 & 53.878 & 4.797 & 0.199 & & \\
\hline \multirow[t]{3}{*}{ Deadlines } & Female & 397 & 54.016 & 4.324 & 0.218 & \multirow[t]{3}{*}{.466} & \multirow[t]{3}{*}{.645} \\
\hline & Total & 980 & 53.938 & 4.709 & 0.157 & & \\
\hline & Male & 593 & 27.021 & 4.867 & 0.203 & & \\
\hline \multirow[t]{3}{*}{ Organizational Stress } & Female & 397 & 28.249 & 4.890 & 0.246 & \multirow[t]{3}{*}{3.807} & \multirow[t]{3}{*}{$.004 *$} \\
\hline & Total & 980 & 27.519 & 4.907 & 0.157 & & \\
\hline & Male & 593 & 23.709 & 3.148 & 0.120 & & \\
\hline \multirow[t]{3}{*}{ Environmental Stress } & Female & 397 & 23.011 & 3.415 & 0.172 & \multirow[t]{3}{*}{3.234} & \multirow[t]{3}{*}{$.001^{*}$} \\
\hline & Total & 960 & 23.435 & 3.283 & 0.125 & & \\
\hline & Male & 573 & 25.099 & 3.804 & 0.163 & & \\
\hline \multirow[t]{3}{*}{ Psychology Stress } & Female & 389 & 24.977 & 4.089 & 0.231 & \multirow[t]{3}{*}{.546} & \multirow[t]{3}{*}{.675} \\
\hline & Total & 976 & 25.073 & 3.786 & 0.109 & & \\
\hline & Male & 588 & 24.839 & 5.426 & 0.236 & & \\
\hline \multirow[t]{3}{*}{ Emotional Stress } & Female & 383 & 25.899 & 5.045 & 0.269 & \multirow[t]{3}{*}{2.545} & \multirow[t]{3}{*}{$.021 *$} \\
\hline & Total & 970 & 25.295 & 5.297 & 0.180 & & \\
\hline & Male & 583 & 34.160 & 4.984 & 0.204 & & \\
\hline \multirow{2}{*}{ Individual Stress } & Female & 387 & 35.684 & 5.643 & 0.265 & \multirow{2}{*}{1.534} & \multirow[t]{2}{*}{.132} \\
\hline & Total & 970 & 35.356 & 5.240 & 0.156 & & \\
\hline
\end{tabular}

The calculated t value $0.627,0.420,0.465,0.5471 .533$ is not significant at five per cent level. The value indicates that there is no significant differentiation between demographic profiles of the employees with respect to the stress factors like non flexible working hours, individual stress, emotional stress, environmental stress, organizational stress etc. Hence, the formulated hypothesis
Testing the significant differentiation between demographic profiles of the employees with respect to the stress factors.

H02: There is significant differentiation between demographic profiles of the employees with respect to the stress factors.

Source: Computed from Primary data * Significant at 5 per cent level 
The calculated $t$ value of $0.203,0.531,0.580,1.226$ and it is not weighty at five per cent level. The value indicates that there signifi-cant differentiation between demographic profiles of the employees with respect to the stress factors. The individual and also the organ-ization need to take necessary steps in coping stress factors so that they can reduce the risk on its employees and also on the organiza-tion. They must implement some significant practices to reduce the stress factors among the individuals so that the employee feels safe and secure in the organization. The stress influences the health fac-tors of the employees. There was more impact of stress on female employees when compared to the male employees.

Testing the significant differentiation between the different stress factors with respect to their Age

$\mathrm{H} 02$ (a): There is no significant differentiation between the different stress factors with respect to their Age

Table 2: T Test for Impact and Management of Stress Factors on the Source of Gender

\begin{tabular}{|c|c|c|c|c|c|c|c|}
\hline Variables & Gender & $\mathrm{N}$ & Mean & SD & $\mathrm{SE}_{\mathrm{M}}$ & t-value & Sig. (2-tailed) \\
\hline \multicolumn{8}{|l|}{ Impact of Stress } \\
\hline \multirow{4}{*}{ Impact of Stress } & Male & 47.290 & 582 & 7.149 & 0.296 & \multirow{3}{*}{0.203} & \multirow{3}{*}{0.839} \\
\hline & Female & 47.374 & 388 & 5.591 & 0.284 & & \\
\hline & Total & 47.324 & 970 & 6.567 & 0.211 & & \\
\hline & Male & 32.036 & 582 & 5.507 & 0.228 & \multirow{2}{*}{2.308} & \multirow{2}{*}{$0.021 *$} \\
\hline \multirow[t]{3}{*}{ Stress impact in the work } & Female & 32.797 & 388 & 4.767 & 0.242 & & \\
\hline & Total & 32.339 & 970 & 5.239 & 0.168 & \multirow{3}{*}{3.011} & \multirow{3}{*}{$0.003 *$} \\
\hline & Male & 35.097 & 582 & 5.783 & 0.240 & & \\
\hline Stress impact on family & Total & 35.517 & 970 & 5.506 & 0.179 & & \\
\hline \multicolumn{8}{|l|}{ Managing Stress } \\
\hline \multirow{7}{*}{$\begin{array}{l}\text { Flexible Working Hours } \\
\text { Team Meets }\end{array}$} & Male & 52.704 & 582 & 6.009 & 0.247 & \multirow[t]{2}{*}{3.696} & \multirow{4}{*}{$0.001 *$} \\
\hline & Female & 51.423 & 388 & 4.764 & 0.247 & & \\
\hline & Total & 52.193 & 970 & 5.576 & 0.177 & 0.531 & \\
\hline & Male & & & & & & \\
\hline & Female & 52.506 & 582 & 6.091 & 0.259 & 0.531 & \multirow{2}{*}{0.595} \\
\hline & Total & 52.724 & 388 & 6.542 & 0.336 & & \\
\hline & Female & 42.257 & 582 & 5.164 & 0.215 & 0.554 & \multirow{3}{*}{0.580} \\
\hline \multirow[t]{2}{*}{ Recreation \& Sports } & Total & 42.430 & 388 & 4.545 & 0.237 & & \\
\hline & Total & 42.326 & 970 & 4.925 & 0.159 & & \\
\hline \multicolumn{8}{|l|}{ Organizational Health } \\
\hline \multirow{2}{*}{ Health Clubs } & Female & 46.242 & 582 & 6.244 & 0.257 & & \multirow[b]{2}{*}{0.220} \\
\hline & Total & 45.799 & 388 & 4.973 & 0.251 & & \\
\hline
\end{tabular}

Table 3: One Way ANOVA for Various Stress Factors Because of Age

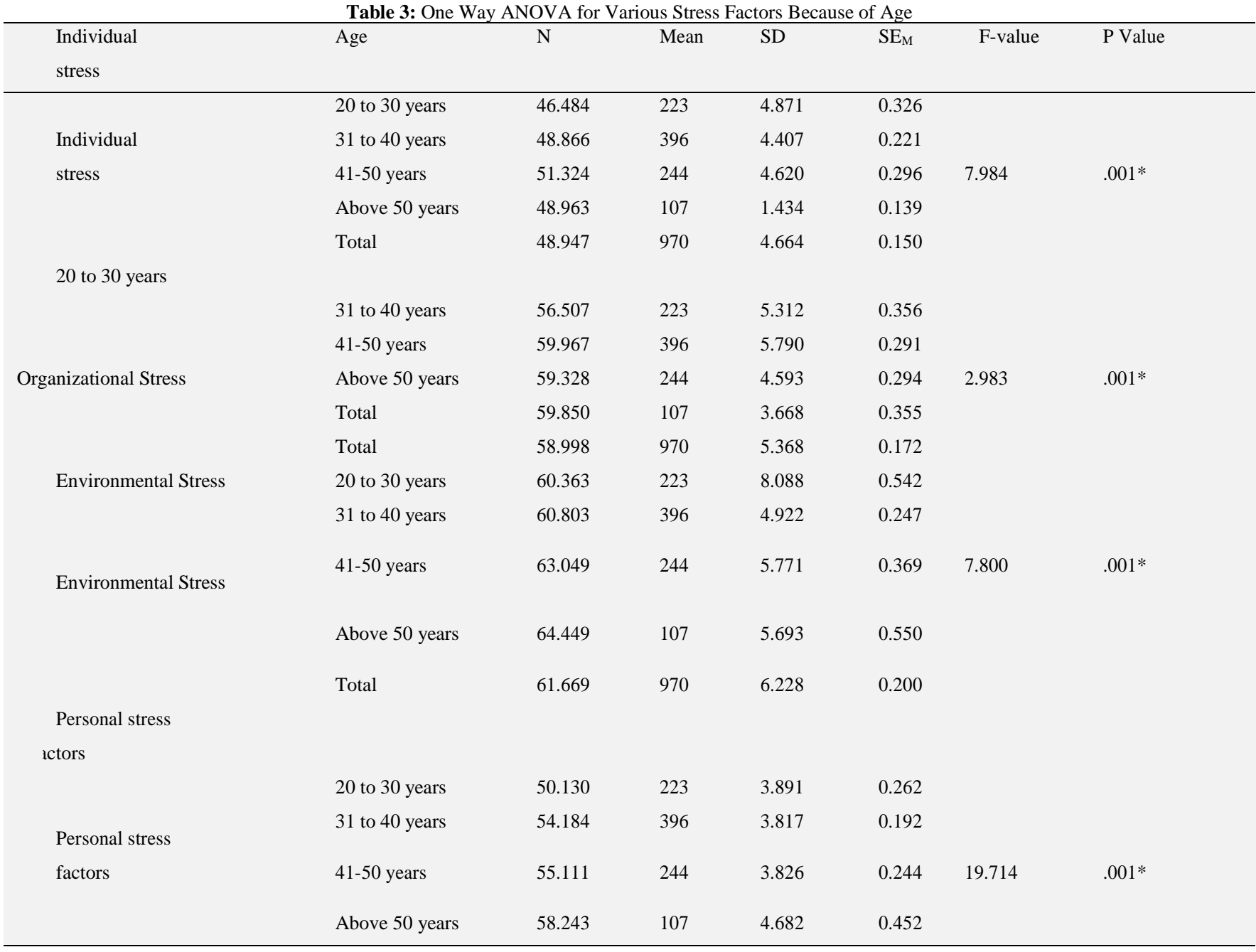




\begin{tabular}{|c|c|c|c|c|c|c|c|}
\hline \multirow[t]{4}{*}{20 to 30 years } & Total & 53.933 & 970 & 4.608 & 0.148 & & \\
\hline & 31 to 40 years & 26.570 & 223 & 5.518 & 0.370 & & \\
\hline & $41-50$ years & 27.859 & 396 & 4.859 & 0.244 & & \\
\hline & Climatic Stress & 26.877 & 244 & 4.043 & 0.259 & 1.768 & $.001 *$ \\
\hline \multirow{3}{*}{$\begin{array}{l}\text { Climatic Stress } \\
20 \text { to } 30 \text { years }\end{array}$} & Above 50 years & 29.626 & 107 & 4.801 & 0.464 & & \\
\hline & Total & 27.510 & 970 & 4.906 & 0.158 & & \\
\hline & 31 to 40 years & 20.915 & 223 & 1.961 & 0.134 & & \\
\hline \multirow[t]{4}{*}{ Physical Stress } & $41-50$ years & 22.939 & 396 & 3.384 & 0.173 & & \\
\hline & & 25.730 & 244 & 2.357 & 0.151 & 39.331 & $.001 *$ \\
\hline & Above 50 years & 25.215 & 107 & 2.223 & 0.214 & & \\
\hline & Total & 23.427 & 970 & 3.274 & 0.105 & & \\
\hline \multicolumn{8}{|l|}{0 to 30 years } \\
\hline & 31 to 40 years & 22.955 & 223 & 4.293 & 0.287 & & \\
\hline \multirow[t]{5}{*}{ Psychological Stress } & $41-50$ years & 25.023 & 396 & 3.643 & 0.183 & & \\
\hline & & 25.967 & 244 & 3.312 & 0.212 & 3.368 & $.001 *$ \\
\hline & Above 50 years & 27.271 & 107 & 2.587 & 0.250 & & \\
\hline & Total & 25.033 & 970 & 3.858 & 0.124 & & \\
\hline & 31 to 40 years & 22.830 & 223 & 6.097 & 0.409 & & \\
\hline \multirow[t]{5}{*}{ Emotional Stress } & $41-50$ years & 24.609 & 396 & 5.001 & 0.252 & & \\
\hline & & 27.701 & 244 & 3.595 & 0.231 & 4.782 & $.001 *$ \\
\hline & Above 50 years & 27.150 & 107 & 4.956 & 0.480 & & \\
\hline & Total & 25.258 & 970 & 5.298 & 0.170 & & \\
\hline & 31 to 40 years & 32.466 & 223 & 4.500 & 0.302 & & \\
\hline \multirow[t]{4}{*}{ Social Stress } & $41-50$ years & 35.611 & 396 & 6.049 & 0.303 & & \\
\hline & & 37.135 & 244 & 3.442 & 0.221 & 6.457 & $.001 *$ \\
\hline & Above 50 years & 36.206 & 107 & 4.708 & 0.454 & & \\
\hline & Total & 35.337 & 970 & 5.270 & 0.169 & & \\
\hline
\end{tabular}

Source: computed from primary data $*$ Significant at 5 per cent level.

The calculated $\mathrm{F}$ value of $47.984,22.983,17.800,119.714$, $11.768,139.331,43.368,44.782$ and 36.457 is recorded in the above respective variables. Hence the formulated hypothesis.

REASON FOR STRESS-(Comparative Studies of the Reasons for Various Stress Factors)

The reason for Stress at work place among the employees in the following companies has been presented in Table 1.4 (a)

\section{Table 4: A) Reason for Stres}

\begin{tabular}{lllll}
\hline Name of the & No. of Re- & Mean & Standard & Coefficient of \\
Company & spondents & Score & Deviation & Variation \\
\hline Cognizant & 270 & 48.83 & 4.57 & 20.93 \\
Verizon & 200 & 47.67 & 7.30 & 53.24 \\
Valuelabs & 250 & 49.14 & 4.57 & 20.88 \\
Infosis & 160 & 48.80 & 4.85 & 23.51 \\
HP & 90 & 48.96 & 4.63 & 21.44 \\
Total & 970 & 48.68 & 5.31 & 28.22 \\
\hline
\end{tabular}

Source: Computed from Primary Data.

Table 1.4(a) indicates the Valuelabs has the highest average acceptance score of 49.14. HP Technologies has the average receipt score of 48.96. The Cognizant with average receipt score of 48.83 . The Infosis has an average acceptance score of 48.80. The Verizon has the least average receipt score 47.67.

Testing the significant difference between reasons for stress H03: There is no significant differentiation between comparative studies of the reasons for various stress factors.

Table 4: B): One Way ANOVA for Reason for Stress

\begin{tabular}{llllll}
\hline & Sum of Squares & Df & Mean Square & F & Sig. \\
\hline Among Clusters & 275.114 & 4 & 68.529 & 2.443 & .045 \\
Within Clusters & 27070.240 & 965 & 28.052 & & \\
Total & 27344.355 & 969 & & & \\
\hline
\end{tabular}


Source: Computed from Primary Data.

From the Table 1.4(b), it clearly shows that:

The measured $F$ value of 2.443 is significant. The $F$ value depicts that there is a significant differentiation in the reason for stress among the employees.

\section{Conclusion}

In the current study, we attempted to compile the work done in the field of Stress at work place and its relationship with Organizational Performance to find how Stress at work place affects employee performance. The research indicates that decrease in productivity, higher attrition rates, debilitated leaves, mishaps; low employment fulfillment, low quality products and services, poor internal communication and clashes inside the corporation are the key consequences of Stress at work place and are major reasons for the outcomes of Stress at work place. While nature of work, the working environment, work schedules, resources and equipment have been found as major factors contributing to Stress. A model has been derived in this research that depicts the relationship between the various variables that contribute to Stress at work place and its impact on organization.

\section{References}

[1] Anderson, E. S. (2002) Social- Cognitive determinants of stress. Health Pyschology 19, 479-486.

[2] Backs, R. W. (2001) an autonomic space approach to the psychophysiological assessment of workload. In P. A. Hncock, \& P. A Desmond, Stress, workload, and fatigue (pp. 279-289). Mahwah, NJ: L. Erlbaum.

[3] Bono, J. E. Folders, H. J. Vinson, G., \&Muros, J. P. (2007). Workplace emotions: the role of supervision and leadership. Journal of Applied psychology, 92(5), 1357-1367.

[4] Caldwell, J. A. (1997). An in-flight investigation of the efficacy of dextroamphetamine for sustaining helicopter pilot performance. Aviation, Space, and Environmental Medicine, 68, 1073-1080.

[5] Christo, B. and Piernaar, J. (2006), South Africa Correctional Official Stress at work place: The Role of Psychological Strenghts, Journal of Criminal Justice, 34(1): 73-84

[6] Critchley, H.D., Mathias, C.J. (2003). Blood pressure, attention and cognition: drivers and air traffic controllers. Clinical Autonomic Research, 13, 399-401.

[7] Delve, L. Skagert, K. \&Vilhelmsson, R. (2007). Leadership in workplace health promotion projects: 1 -and 2-year effects on longterm work attendance. European Journal of public Health, 17 (5), 471-476.

[8] Hetland, H. Sandal, G. M. \&Johnsen, T.B. (2007). Burnout in the information technology sector:Does leadership matter?. European Journal of work and organizational psychology, 16 (1).

[9] Ornelas, S. and Kleiner, B. H. (2003), New Development in Managing Job Related Stress, Journal of Equal Opportunities International, 2(5): 64-70.

[10] Rayner, C. \&Mclvor, K. (2006). Report to the Dignity at Work project Steering Committee. Dignity at work report: Portsmouth University.

[11] Schaubroeck, J. Walumbwa, F, F. O., Ganster, D. C. \&Kepe, S (2007). Destructive leadership traits and the neutralising influence of an 'enriched' job. Leadership Quarterly, 18(3), 236-251.

[12] Vermut, R. and Steensma, H. (2005), how can Justice be Used to Manage Stress in Organizations, in Greenberg, J.A. (Eds.), Handbook of Organizational Justice, pp. 383-410, Earlbaum, Mahwah, NJ.

[13] Wager, N., Fieldman, G., Hussey, T. (2003). The effect on ambulatory blood pressure of working under favourably and unfavourably perceived supervisors. Work and environmental Medicine, 60, 468474.

[14] Erkutlu HV, Chafra J (2006). Relationship between leadership power bases and job stress of subordinates: example from boutique hotels. Management Research News 29(5): 285-297.

[15] Jayashree, R., (2010). Stress Management with Special Reference to Public Sector Bank Employees in Hyderabad. International Journal of Enterprise and Innovation Management Studies (IJEIMS) Vol. 1 No. 3, Pp. 34- 35. 